\title{
Chemokine receptor 7 promotes cell migration and adhesion in metastatic squamous cell carcinoma of the head and neck by activating integrin $\alpha v \beta 3$
}

\author{
PENG LI ${ }^{1,2}$, FAYU LIU $^{1,2}$, LIYAN SUN $^{3}$, ZHENJIN ZHAO ${ }^{3}$, XUE DING $^{1,2}$, \\ DEHAO SHANG ${ }^{1,2}$, ZHONGFEI XU ${ }^{1,2}$ and CHANGFU SUN ${ }^{1,2}$ \\ Departments of ${ }^{1}$ Oromaxillofacial-Head and Neck Surgery, ${ }^{2}$ Oral Maxillofacial Surgery and ${ }^{3}$ Orthodontics, \\ School of Stomatology, China Medical University, Heping District, Shenyang, Liaoning 110002, P.R. China
}

Received December 2, 2010; Accepted January 21, 2011

DOI: $10.3892 /$ ijmm.2011.628

\begin{abstract}
The mechanisms leading to squamous cell carcinoma of the head and neck (SCCHN) metastasis are incompletely understood. Although evidence shows that the chemokine receptor 7 (CCR7) and its ligand CCL19 may regulate tumor dissemination, their role in SCCHN is not clearly defined. CCR7 has been shown to regulate integrins, which facilitate adhesion of cancer cells to and/or migration through the extracellular matrix (ECM). To investigate the relationship between CCR7 and integrin $\alpha v \beta 3$ in metastatic SCCHN, we used adhesion and migration assays, immunofluorescence staining and Western blotting to determine whether integrin $\alpha v \beta 3$ can be activated by CCL19 in the metastatic SCCHN cell line PCI-37B, which was pre-incubated with CCL19 or the integrin $\alpha v \beta 3$ inhibitor, IS201. Our results demonstrate that CCR7 favors PCI-37B cell adhesion and migration, induces reorganization of the actin cytoskeleton and induces integrin $\alpha v \beta 3$ phosphorylation. The integrin $\alpha v \beta 3$ inhibitor, IS201, blocked all of these effects. CCR7 and integrin $\alpha v \beta 3$ expression significantly and positively correlated with tumor size, clinical stage and nodal metastasis. Taken together, our data indicate that CCR7 regulates cell adhesion and migration via integrin $\alpha v \beta 3$ in metastatic SCCHN. These results should provide the groundwork for new strategies aimed at preventing SCCHN metastasis.
\end{abstract}

\section{Introduction}

Metastasis, the leading cause of death in cancer patients, is a complex, non-random and organ-specific process, which

Correspondence to: Dr Changfu Sun, Department of Oromaxillofacial-Head and Neck Surgery, School of Stomatology, China Medical University, 117 Nanjing Bei Jie, Heping District, Shenyang, Liaoning 110002, P.R. China

E-mail: changfusun@hotmail.com

Key words: chemokine receptor 7, squamous cell carcinoma of the head and neck, adhesion, migration, integrin $\alpha v \beta 3$ depends on the successful accomplishment of several sequential steps by the tumor cells, from the primary tumor to the secondary organs (1). Two main theories, which are the 'seed and soil' concept and the 'homing theory', have been proposed to explain the organ specificity seen for many tumors. Nevertheless, our knowledge of the molecular mechanisms underlying the metastatic process is still limited. Migration and adhesion of tumor cells may be essential prerequisites for the formation of metastases in malignant diseases.

Squamous cell carcinoma of the head and neck (SCCHN), a malignant tumor of epithelial origin, accounts for more than $90 \%$ of all head and neck cancers (2). The 5-year survival rate of less than $30 \%$ is due to a high lymphogenic metastatic tendency, a high recurrence rate, and an increased occurrence of secondary tumors. No significant increase in the long-term SCCHN survival rate has been achieved in the past 30 years, despite substantial improvements in diagnosis, local management, and chemotherapy. Novel targets that can serve as the foundation for biologically based therapeutic strategies are needed (3).

The chemokines are a superfamily of low molecular weight $(8-10 \mathrm{kDa})$ peptides, initially characterized by their ability to induce migration of leukocytes. Chemokines are classified into four highly conserved groups: CXC, CC, C, and $\mathrm{CX} 3 \mathrm{C}$, based on the position of the first two cysteines adjacent to the amino terminus. Since chemokine receptors were found to be expressed in cancers, it was concluded that chemokine/ receptor pairs may also control the migration of tumor cells through the endothelial vessel wall and ECM. The chemokine receptor 7 (CCR7) and its two ligands, CCL19 and CCL21, are thought to play a central role in regulating migration of lymphocytes to lymph nodes and metastasis of many solid tumors. For example, this signaling pathway is involved in the migration of mature dendritic cells (DCs) (4), T and B cells (5), non-small cell lung cancer $(6,7)$, gastric carcinoma (8), colorectal carcinoma (9) and SCCHN (2,3,10,11).

Integrins are a family of transmembrane glycoproteins that mediate cell-cell and cell-matrix interaction (12). All known members of this superfamily are non-covalently associated heterodimers composed of an $\alpha$ and a $\beta$ subunit. At present, at least $8 \beta$ and $18 \alpha$ subunits have been characterized. For 
instance, subunit $\beta 3$ associates with subunits $\alpha \mathrm{IIb}$ and $\alpha \mathrm{v}$ to generate integrins $\alpha \operatorname{IIb} \beta 3$ and $\alpha v \beta 3$. The $\alpha v \beta 3$ integrin is one of the most prevalent integrins - expressed on almost all the cells originating from the mesenchyme and on a variety of cell types in the blood vessel. It is known to mediate many biological events, such as the migration of vascular smooth muscle cells and adhesion of osteoclasts to the bone matrix as well as angiogenesis and revascularization of chronic wounds during granulation tissue formation (13). Changes in integrin expression level and activation state have been extensively documented in tumor cells and are thought to contribute to neoplastic progression. Altered expression of $\alpha v \beta 3$ integrin has been detected in different types of tumors, including breast $(14,15)$, prostate $(16)$ and ovarian (17) cancers, melanomas $(18,19)$, and gliomas $(20)$, and this expression has been correlated with an aggressive phenotype and metastatic dissemination.

Recently, a new role was described for the chemokine family: signaling via chemokine receptors can modulate tumor cell expression of integrins, which can then facilitate adhesion of cancer cells to and/or invasion through the ECM. CXCR4 chemokine receptor mediates prostate tumor cell adhesion through $\alpha 5$ and $\beta 3$ integrins (21). CCL21 promotes the migration and adhesion of lymph node metastases of human non-small cell lung cancer via integrins (22). Binding of the chemokine CCL19/CCL21 to its receptor, CCR7, increases adhesive properties of human mesangial cells by regulating integrins (23).

Given the extensive data suggesting that activation of integrins by CCR7 is involved in the adhesion and migration of prostate cancer $(16,24)$, lymphocytic leukemia cells $(4,12)$, renal carcinoma cells (25), DC cells (26), thyroid carcinoma cells (27) and breast carcinoma cells $(14,15)$, we hypothesized that CCR7 might regulate cell adhesion and migration via the $\alpha v \beta 3$ integrin in SCCHN. This study was designed to determine whether the $\alpha v \beta 3$ integrin could be activated by CCR7 and to investigate its role in adhesion and migration in metastatic SCCHN.

\section{Materials and methods}

Human tumor samples and cell lines. Seventy-eight SCCHN tumor specimens with adjacent metastatic (or normal) lymph nodes and ten specimens of normal human oral mucosal tissue were obtained by biopsy prior to chemotherapy or radiotherapy from the Head and Neck Tumor Center, School of Stomatology, China Medical University. SCCHN classification, including primary tumors $(\mathrm{T})$, regional lymph nodes $(\mathrm{N})$, distant metastasis (M) and stage grouping, was determined according to the rules of the International Union Against Cancer (UICC) for Head and Neck Cancer (Tumor node metastasis, TNM classification, 1997).

PCI-37B, which are well-characterized SCCHN cell lines derived from the metastatic lymph node of SCCHN patients, were kindly donated by the University of Pittsburgh Cancer Institute. PCI-37B cells were cultured as previously described $(10,11,28)$ in Dulbecco's modified Eagle's medium (DMEM) (Invitrogen, Carlsbad, CA, USA), supplemented with $10 \%$ fetal bovine serum (FBS) (Gibco, Carlsbad, CA, USA), $100 \mathrm{U} / \mathrm{ml}$ penicillin $\mathrm{G}$, and $100 \mathrm{U} / \mathrm{ml}$ streptomycin in an atmosphere of
$95 \%$ air $/ 5 \% \mathrm{CO}_{2}$ at $37^{\circ} \mathrm{C}$. When inhibitors were used, inhibitor treatment at the dose used did not affect the viability or expression of CCR7 by the cells.

Reagents and antibodies. CCL19, CCR7-specific monoclonal antibody (mouse anti-human CCR7), $\alpha \mathrm{v} \beta 3$ integrin, bovine serum albumin (BSA), and fibronectin (FN) were purchased from R\&D Systems (Minneapolis, MN, USA). Matrigel ${ }^{\text {TM }}$ Basement Membrane Matrix was purchased from BD Bioscience Pharmingen (Rockville, MD, USA). The integrin inhibitor, IS201, rhodamine-labeled phalloidin, 3-(4,5-dimethyl-2-tetrazoly)-2,5-diphenyl-2H tetrazolium bromide (MTT), and dimethyl sulfoxide (DMSO) were purchased from Sigma (St. Louis, MO, USA)

Cell adhesion-MTT assay. The MTT assay is a quantitative colorimetric method to determine cell proliferation. It utilizes the yellow tetrazolium salt [3-(4,5-dimethylthiazol2-yl)-2,5-diphenyltetrazolium-bromide] which is metabolized by mitochondrial succinic dehydrogenase activity of proliferating cells to yield a purple formazan reaction product. Cell adhesion assays were performed in 96-well plates (Corning Costar, Cambridge, MA, USA) coated with BSA, Matrigel and FN. Matrigel and FN served as the test basements, and BSA as the contrast basement. The plates were incubated at room temperature overnight, and then hydrated by $0.1 \%$ BSA for $1 \mathrm{~h}$ at $37^{\circ} \mathrm{C}$. To determine the optimal density (OD) of IS201 and the experimental duration needed to reveal the effects on PCI-37B cell adhesion, PCI-37B cells were treated with or without IS201 at different concentration or for different durations. The cells were then treated with CCL19, plated in the 96-well plates at increasing cell numbers, and washed three times with phosphate-buffered saline (PBS). Next, the cells were incubated with MTT $(20 \mu 1,5 \mu \mathrm{g} / \mathrm{ml})$ for $4 \mathrm{~h}$ and then exposed to DMSO (Sigma) to lyse the cells. The OD was read on a spectrophotometer (Sunrise RC, Tecan, Switzerland) through a 490-nm filter. Eight wells were analyzed in parallel for each experimental condition. Adhesion index $(\%)=[($ Matrigel or FN conditions cell OD/ BSA conditions cell OD)-1] x100\%.

Transwell assay. Migration was assayed in Transwell filter insert chambers ( $8 \mu \mathrm{m}$ pore size; Corning Costar) as previously described $(4,11,22)$. The upper surface of the chamber contained a Transwell filter $(8-\mu \mathrm{m}$ pore size polyvinyl pyrrolidone-free). CCL19 (final density of $500 \mathrm{ng} / \mathrm{ml}$ ) was placed in the lower wells. PCI-37B cells treated with or without IS201 at different concentrations or for different durations were removed from the culture flasks and added to the upper chamber. After $60 \mathrm{~min}$ at $37^{\circ} \mathrm{C}$, a cotton-tipped swab was inserted into the chamber to remove non-invading cells by applying gentle but firm pressure while moving the tip around the membrane surface. The lower filter surfaces were fixed with methanol and stained with hematoxylin. Cells that had migrated to the lower surface were counted under a microscope (Nikon TE2000-S Eclipse, Tokyo, Japan) at x200 magnifications. The mean number of cells per field in 10 random fields was recorded. For each experimental condition, four to five wells were analyzed in parallel. The data are expressed at the average number ( \pm standard deviation, SD) of 
cells from 10 fields that migrated to the lower surface of the filter from each of the three experiments performed.

Monolayer wound assay. Migration of PCI-37B cells was investigated through an in vitro monolayer wound assay (29). Cells grown in 24-well plates in DMEM to confluence were scrapped with a pipette tip to create a cell-free area. Wounded monolayers were washed with serum-free media to remove cell debris and incubated with serum-free DMEM containing either CCL19 $(500 \mathrm{ng} / \mathrm{ml})$ or IS201 $(10 \mu \mathrm{g} / \mathrm{ml})$. Wound closure was followed after 0,24 and $48 \mathrm{~h}$. The wound healing effect was calculated as the percentage of the remaining cell-free area compared to the initial wound area (arbitrarily set as $100 \%$ ). All monolayer wound assays included serum-free DMEM controls. The wounds were observed by phase contrast microscopy (Nikon TE2000-S Eclipse) at x200 magnifications and documented by photography. Each experiment was performed in triplicate analyzing four or five scratches per well.

Immunofluorescence staining. PCI-37B cells were grown on glass coverslips, serum-starved for $24 \mathrm{~h}$ and cultured in 24-well plates (Corning Costar), and then treated with or without IS201 for $4 \mathrm{~h}$, followed by CCL19 (final density of $500 \mathrm{ng} / \mathrm{ml}$ ) for $30 \mathrm{~min}$ at $37^{\circ} \mathrm{C}, 5 \% \mathrm{CO}_{2}$. The cells were fixed in $2.5 \%$ glutaraldehyde for $10 \mathrm{~min}$, lysed with $0.1 \%$ Triton X-100 for $5 \mathrm{~min}$ at $37^{\circ} \mathrm{C}$, and incubated overnight at $37^{\circ} \mathrm{C}$ with the $\alpha v \beta 3$ integrin primary antibody (1:100). The next day the coverslips were washed with PBS twice followed by cell staining with $50 \mu 1$ rhodamine-labeled phalloidin, diluted to a final concentration of $10 \mu \mathrm{g} / \mathrm{ml}$ (1:100) in PBS for half an hour. Once again the cover-slips were washed with PBS for three times and the cell morphology was analyzed with an inverted microscope (Nikon TE2000-S Eclipse) at x800 magnification. For each experimental condition, four to five wells were analyzed in parallel.

Western blotting. PCI-37B cells were treated with or without the $\alpha v \beta 3$ integrin inhibitor, IS201, or the CCR7 $\mathrm{mAb}$ and then exposed to CCL19 at a concentration of $500 \mathrm{ng} / \mathrm{ml}$ for $1 \mathrm{~h}$. Whole cells were harvested in lysis buffer $(10 \mathrm{mM}$ Tris- $\mathrm{HCl}$ $\mathrm{pH}$ 7.6, $50 \mathrm{mM} \mathrm{Na} \mathrm{P}_{2} \mathrm{O}_{7}, 50 \mathrm{mM} \mathrm{NaF}, 1 \mathrm{mM} \mathrm{NaV} \mathrm{O}_{4}, 1 \%$ Triton $\mathrm{X}-100$ and $1 \mathrm{X}$ protease inhibitor of protein tyrosine phosphatases). Lysates were sonicated for $3 \mathrm{sec}$ and then centrifuged at $14,000 \mathrm{rpm}$ at $4^{\circ} \mathrm{C}$ for $30 \mathrm{~min}$. The protein concentration of the lysate was determined using the Bio-Rad protein assay dye reagent (Bio-Rad Laboratories, Richmond, CA, USA), and then the protein was normalized for equal loading using a standard curve (Sigma Diagnostics, USA). The protein $(50 \mu \mathrm{g})$ was size-fractionated through a $10 \%$ SDS-PAGE gel and transferred onto nitrocellulose filters (Schleicher and Schuell, Dassel, Germany). The filter was blocked in PBS containing 1\% skim milk, 0.1\% Triton X-100, $\mathrm{NaCl}$ and Tris [tris(hydroxymethyl)aminomethane] overnight at $4^{\circ} \mathrm{C}$. The membrane was then incubated with the $\alpha v \beta 3$ integrin rabbit antibody (1:1000) for $1 \mathrm{~h}$ at room temperature, followed by a horseradish peroxidase-conjugated secondary antibody (goat anti-rabbit, Sigma). $\beta$-actin (1:1000) served as the internal control. Bands were visualized using an enhanced chemiluminescence system (Amersham Pharmacia Biotech,
Piscataway, NJ, USA) and quantified by scanning densitometry using FluorChem v2.0 software.

Immunohistochemical analysis. The study protocol was approved by the Medical Ethics Committee of the China Medical University and performed according to the declaration of Helsinki. All of the specimens were obtained with the consent of the patients before surgery and in accordance with Health Insurance Portability. Written informed consent was obtained from all individuals. The specimens were subjected to immunohistochemistry using conventional horseradish peroxidase staining methods.

To inhibit endogenous peroxide activity, sections were immersed in $100 \%$ methanol containing $0.3 \%$ hydrogen peroxide for $40 \mathrm{~min}$. After antigen retrieval was performed, the sections were incubated with normal blocking serum for $10 \mathrm{~min}$, then with the CCR7-specific monoclonal antibody and the $\alpha v \beta 3$ integrin antibody (1:100) overnight at $4^{\circ} \mathrm{C}$. After the incubation period, sections were washed three times with PBS and were then incubated with the linking reagent (R\&D Systems) at room temperature for $1 \mathrm{~h}$. Sections were further incubated with a complex of avidin DH and biotinlylated enzyme (Zymed) for $30 \mathrm{~min}$, after three washes with PBS. The sections were incubated with a medium consisting of an equal volume of $0.02 \%$ hydrogen peroxide and diaminobenzidine for visualization. All sections were counterstained with hematoxylin (Sigma). Negative controls in which the primary antibody was omitted were run in parallel. The stained slides were investigated independently by two pathologists who had no knowledge of the clinical parameters and outcomes. Cell morphology was analyzed by microscopy (Nikon Eclipse $80 \mathrm{i}$,) at x100 to x400 magnifications.

Tumors were classified according to the percentage of positive tumor cells: no staining observed in any cell $(-),<10 \%$ or no staining; weakly positive $(+), 11-50 \%$; positive $(++)$, $51-75 \%$; or strongly positive $(+++),>75 \%$ positive staining.

Statistical analysis. Numerical data were expressed as mean \pm SD. Statistical significance was determined using the two-tailed Student's t-test, and the minimum acceptable level of significance was set at $\mathrm{P}<0.05$. In MTT assays, data were analyzed by one-way ANOVA followed by the TukeyKramer multiple comparison's test. In immunohistochemical analysis, the correlation between the CCR7 and the $\alpha v \beta 3$ integrin expression in tumor specimens was analyzed by the Spearman's test and the $\chi^{2}$ test. All statistical analyses were performed using the Statistical Package for the Social Sciences (SPSS Inc., Chicago, IL, USA).

\section{Results}

CCL19 triggers and IS201 blocks $\alpha v \beta 3$ integrin-dependent adhesion of PCI-37B cells. We analyzed the time- and dose-dependent effects of IS201 using pre-coated Matrigel (Fig. 1A) and pre-coated FN (Fig. 1B) to determine whether CCL19 affects SCCHN cell adhesion. CCL19-induced the activation of $\alpha v \beta 3$ integrin and significantly enhanced the adhesion index of PCI-37B cells. IS20I is an RGD mimetic compound that is different from other inhibitors of $\alpha v \beta 3$ integrin presently used. It has a cyclic structure that mimics the 

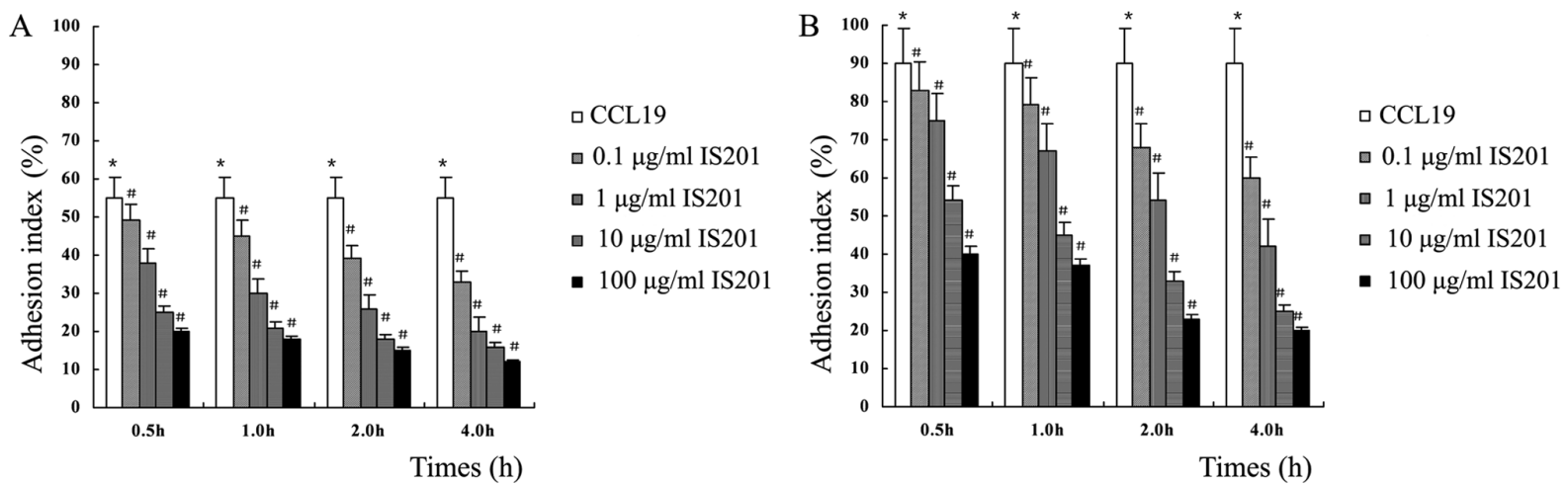

Figure 1. CCL19 induces and IS201 blocks the adhesion of PCI-37B cells. PCI-37B cells ( $8 \times 10^{4}$ cells/well) were plated in 96 -well plates coated with (A) Matrigel $(10 \mathrm{mg} / \mathrm{ml})$ or $(B) \mathrm{FN}(50 \mu \mathrm{g} / \mathrm{ml})$. BSA $(10 \mathrm{mg} / \mathrm{ml})$ served as the contrast basement. IS201 was applied at different concentrations $(0.1-100 \mu \mathrm{g} / \mathrm{ml})$ for different incubation times $(0.5,1,2$ or $4 \mathrm{~h})$. The effects of IS201 + CCL19 $(500 \mathrm{ng} / \mathrm{ml}$ for $30 \mathrm{~min})$ were compared to CCL19 alone (500 ng/ml for $30 \mathrm{~min})$ and to controls. The results shown are representative of three independent experiments. ${ }^{*} \mathrm{P}<0.05$ compared to the untreated group; ${ }^{*} \mathrm{P}<0.05$ compared with the CCL19 group in both pre-coated Matrigel (A) and pre-coated FN (B).

A

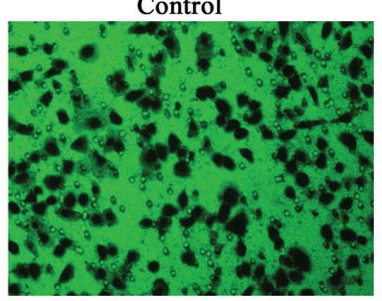

$0.1 \mu \mathrm{g} / \mathrm{ml}$ IS201+CCL19

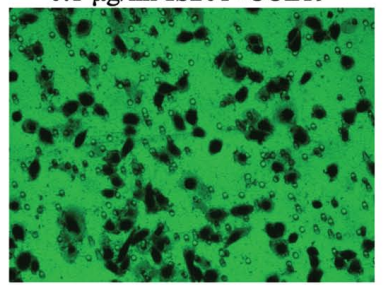

$10 \mu \mathrm{g} / \mathrm{ml}$ IS201+CCL19

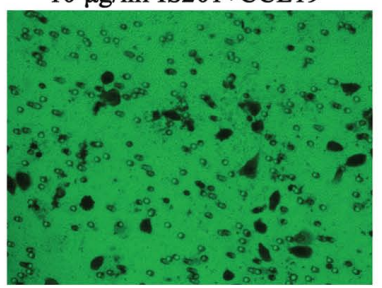

CCL19

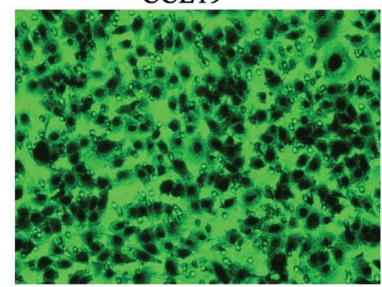

$1 \mu \mathrm{g} / \mathrm{ml}$ IS201+CCL19

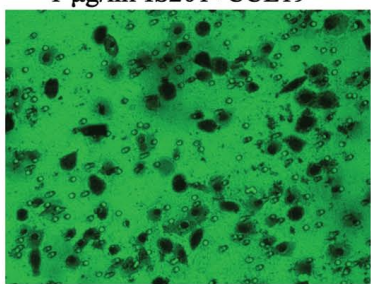

$100 \mu \mathrm{g} / \mathrm{ml}$ IS201+CCL19

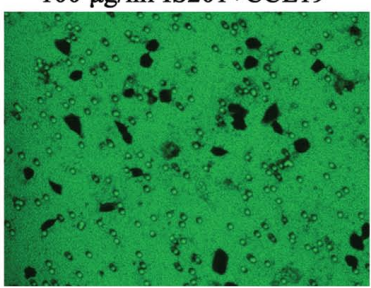

B

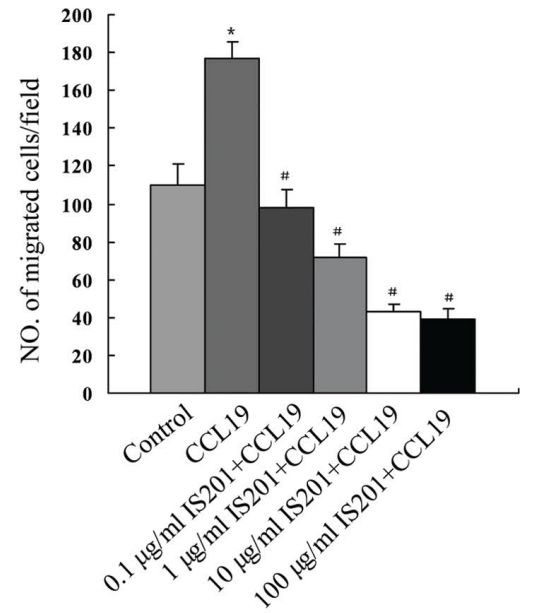

Figure 2. CCL19 induces and IS201 blocks migration of PCI-37B cells (Transwell assay). PCI-37B cells (2x105 cells/100 $\mu 1$ ) treated with different IS201 concentrations $(0.1-100 \mu \mathrm{g} / \mathrm{ml})$ for $4 \mathrm{~h}$ and CCL19 $(500 \mathrm{ng} / \mathrm{ml}$ for $30 \mathrm{~min})$, compared with CCL19-induced (500 ng/ml for $30 \mathrm{~min})$ and to the control. (A) Cells were counted under a microscope at $\mathrm{x} 200$ magnification. The results shown are representative of three independent experiments. (B) CCL19 induced the migration of PCI-37B cells, ${ }^{*} \mathrm{P}<0.05$ compared to the control group. Different concentrations of IS201 blocked the migration of PCI-37B cells as compared to cells treated with CCL19 alone (paired Student's t-test, ${ }^{\#} \mathrm{P}<0.05$ ).

RGD structure of binding and acts as a selective $\alpha v \beta 3$ integrin inhibitor. IS201 and certain synthetic RGD-containing peptides function as competitive, reversible inhibitors of adhesion and have been widely used in studies of cell adhesion and migration and to suppress tumor metastasis. We observed that the PCI-37B adhesion index was effectively blocked by IS201. This effect was seen with several different doses of the inhibitor and various incubation times and on both pre-coated Matrigel and pre-coated FN. The adhesion index values of the two groups were significantly different (one-way ANOVA, $\mathrm{P}<0.05)$.
CCL19 induces and IS201 blocks the migration of PCI-37B cells in both the monolayer wound assay and the Transwell assay. To determine whether CCL19 affects SCCHN cell migration, we analyzed the time- and dose-dependent effects of IS201 using the pre-coated monolayer wound assay (Fig. 3) and the Transwell assay (Fig. 2). Signaling through CCR7 was assessed in an in vitro wound healing model system that requires both migration and proliferation of cells. Defined lesions were generated in subconfluent layers of PCI-37B and the repopulation of denuded areas was studied. Under standard conditions no relevant change of the gap was apparent 

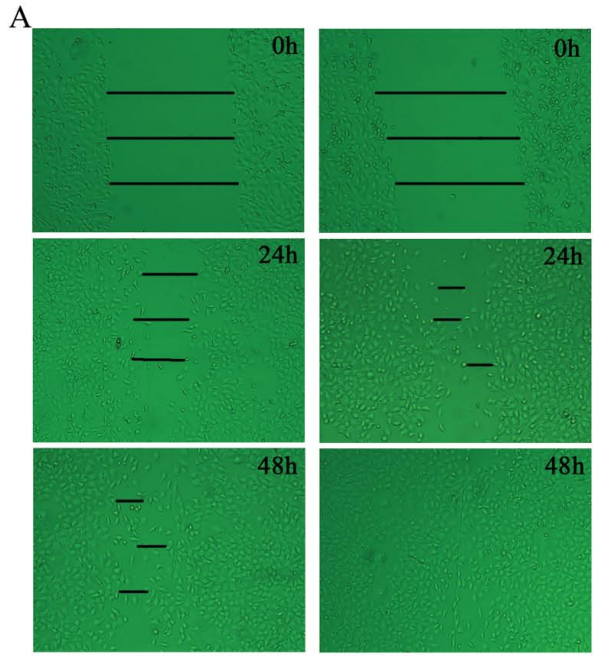

Control

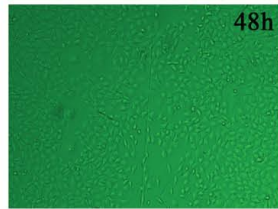

CCL19
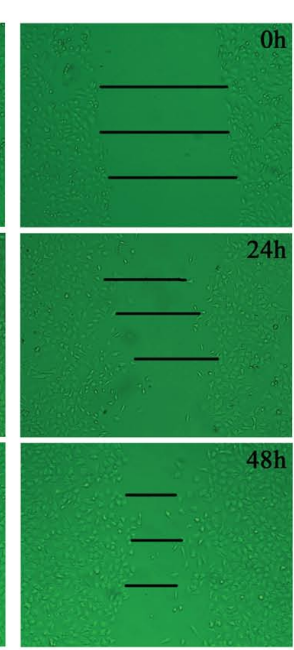

IS201
B

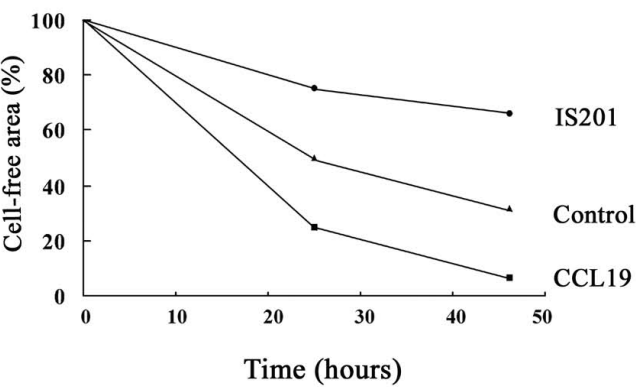

Time (hours)

Figure 3. CCL19 induces and IS201 blocks the migration of PCI-37B cells (Monolayer wound assay). (A) Wounded monolayers (2x10 5 cells/100 $\mu 1)$ were incubated with serum-free DMEM containing either CCL19 $(500 \mathrm{ng} / \mathrm{ml})$ or IS201 $(10 \mu \mathrm{g} / \mathrm{ml})$ and compared to control. Wound closure was followed after 0 , 24 and $48 \mathrm{~h}$. Cells were counted under a microscope at x200 magnification. The results shown are representative of three independent experiments. CCL19 induced the migration of PCI-37B cells, P<0.05 compared to the control group. (B). Different time intervals of IS201 blocked the migration of PCI-37B cells as compared to cells treated with CCL19 alone (paired Student's t-test, $\mathrm{P}<0.05$ ).
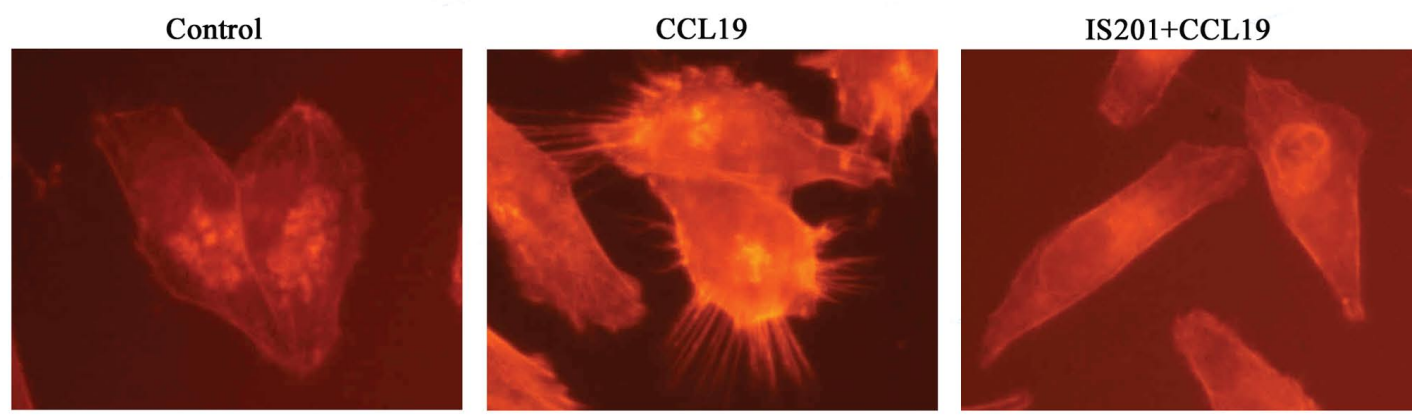

Figure 4. CCL19 induces and IS201 blocks reorganization of the actin cytoskeleton in PCI-37B cells. CCR7 activation led to actin polymerization and formation of filopodia in SCCHN cells, whereas IS201 blocked this effect. PCI-37B cells were left untreated, treated with CCL19 (500 ng/ml) for 1 h, or treated with IS201 $(10 \mu \mathrm{g} / \mathrm{ml})$ for $4 \mathrm{~h}$ and CCL19 $(500 \mathrm{ng} / \mathrm{ml})$ for $1 \mathrm{~h}$. The cells were stained with rhodamine-labeled phalloidin and showed a considerable increase in actin polymerization and cell extensions resembling filopodia upon CCL19 induction; these effects were blocked by IS201.

$12 \mathrm{~h}$ after inducing the lesion. After $24 \mathrm{~h}$ the gap started to close but was still visible at $48 \mathrm{~h}$ (Fig. 3, left panels). In contrast, upon addition of CCL19 accelerated wound closure was already noticeable after $48 \mathrm{~h}$. At $24 \mathrm{~h}$ the lesions were almost closed and at $48 \mathrm{~h}$ the previously cell-free areas were nearly repopulated. Furthermore, no relevant changes of the gap were apparent $24 \mathrm{~h}$ after inducing the lesion and the gap was still visible at $48 \mathrm{~h}$ after addition of IS201.

In the Transwell assay, the conditioned CCL19 medium was placed in the lower part of a Transwell unit and PCI-37B cells were added to the upper part in the presence or absence of IS201. CCL19 significantly enhanced the migration ability of PCI-37B cells. This effect was specifically blocked by IS201. The inhibitory effect intensified with increasing IS201 concentrations, but there was no sharp difference between the concentrations of 10 and $100 \mu \mathrm{g} / \mathrm{ml}$ (Fig. 2).

CCL19 induces and IS201 blocks the reorganization of the actin cytoskeleton of PCI-37B cells. Reorganization of the actin cytoskeleton is an early event in the migratory response to chemokines (17). We used rhodamine-labeled phalloidin staining and inverted microscopy to investigate whether actin polymerization occurred in response to CCL19 and clarify its relationship with $\alpha v \beta 3$ integrin. After $1 \mathrm{~h}$ of CCL19 stimulation, we observed increased actin polymerization and the formation of cell extensions that resembled filopodia (Fig. 4). These effects were clearly inhibited by the presence of IS201.

Phosphorylation of $\alpha v \beta 3$ integrin is activated by CCL19 and blocked by IS201. The level of phosphorylated $\alpha v \beta 3$ integrin was determined by Western blot analysis and quantified by computer-aided densitometry. Integrin phosphorylation serves as a two-sided switch for integrin activation and regulates adhesion, migration and lamellipodial stability. CCL19 induced a 2-fold increase in phosphorylation of $\alpha v \beta 3$ integrin in PCI-37B cells (Fig. 5). CCR7 mAb can neutralize the bioactivity of CCR7 and has been widely used as a CCR7 


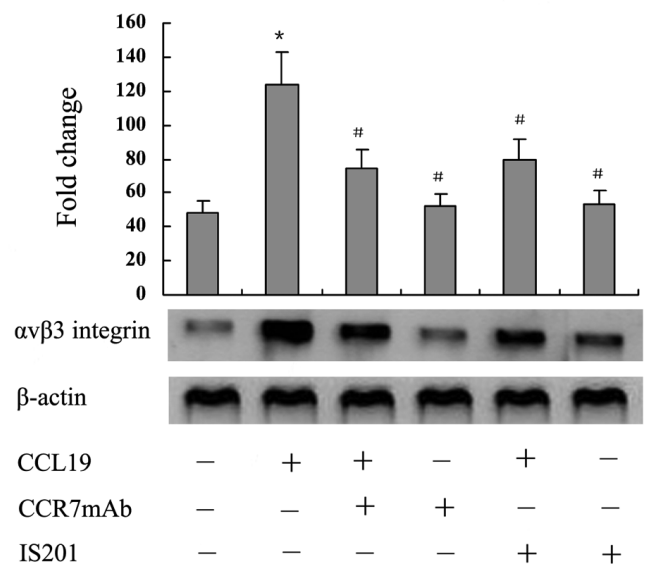

Figure 5. Western blot analysis of $\alpha v \beta 3$ integrin phosphorylation in PCI-37B PCI-37B cells were treated with or without the $\alpha v \beta 3$ integrin inhibitor IS201 $(10 \mu \mathrm{g} / \mathrm{ml})$ or the CCR7 $\mathrm{mAb}(10 \mu \mathrm{g} / \mathrm{ml})$ for $4 \mathrm{~h}$ at $37^{\circ} \mathrm{C}$, followed by CCL19 $(200 \mathrm{ng} / \mathrm{ml})$ at $37^{\circ} \mathrm{C}$ for $1 \mathrm{~h}$. Activation of CCR7 induced $\alpha v \beta 3$ integrin phosphorylation and this effect was blocked by CCR7 mAb and the IS201 inhibitor. The results are representative of three independent experiments. Expression relative to $\beta$-actin is shown as the mean $\pm \mathrm{SD}\left({ }^{*} \mathrm{P}<0.05\right.$ compared to untreated cells, ${ }^{\#} \mathrm{P}<0.05$ compared to cells treated with CCL19 alone).

inhibitor. Phosphorylation of $\alpha v \beta 3$ integrin was diminished by treatment with the CCR7 $\mathrm{mAb}$, suggesting that phosphorylation was induced by CCR7 activation. The positive effect of CCR7 on $\alpha v \beta 3$ integrin phosphorylation was also blocked by IS201, indicating that CCR7 can directly activate $\alpha v \beta 3$ integrin, and that $\alpha v \beta 3$ integrin may be a critical downstream target of integrin/CCR7 signaling.

CCR7 and $\alpha v \beta 3$ integrin expression show a significant positive correlation in tumor tissues and metastatic lymph nodes. We used immunohistochemistry to investigate the expression patterns of CCR7 and $\alpha v \beta 3$ integrin in SCCHN tumor tissues, metastatic lymph nodes, normal lymph nodes and oral mucosal tissues. CCR7 and $\alpha v \beta 3$ integrin were both found in the cell membrane and cytoplasm, mainly in the stroma surrounding tumor cells and metastatic lymph nodes. Few cells expressed CCR7 or $\alpha v \beta 3$ integrin in normal lymph nodes and oral mucosal tissues (Fig. 6 and Table I). CCR7 and $\alpha v \beta 3$ integrin expression were both significantly correlated with cervical lymph node metastasis and SCCHN clinical stage $(\mathrm{P}<0.05)$. In addition, T3/T4 tumors also expressed high levels of $\alpha v \beta 3$ integrin $(\mathrm{P}<0.05)$. However, there were no significant differences in CCR7 or $\alpha v \beta 3$ integrin expression across ages or genders $(\mathrm{P}>0.05)$. A moderate correlation was observed between CCR7 and $\alpha v \beta 3$ integrin expression in SCCHN tumor tissues (Spearman's $r=0.627, \mathrm{P}<0.05$ ) and metastatic lymph nodes (Spearman's $r=0.881, \mathrm{P}<0.05$ ) but not in normal lymph nodes (Spearman's $r=0.205, \mathrm{P}>0.05$ ) or normal oral mucosal tissues (Spearman's $r=0.097, \mathrm{P}>0.05$ ).

\section{Discussion}

The critical problem in SCCHN therapy is the metastasis, especially to the lymph nodes, lung, liver and bone. Metastasis involves cell separation from the primary tumor, migration into the ECM, blood vessel invasion, adhesion to the endothelium and extravasation and growth in a secondary organ (30). Integrins are involved in each step of this metastatic cascade and sustain cell survival and cell-cell interactions in target organs. During these steps, $\alpha v \beta 3$ integrin activates focal adhesion kinase (FAK) to mediate cell-cell adhesion or cell-ECM adhesion, thus affecting signal transduction, proliferation, differentiation, survival and apoptosis. The signals transmitted by integrins exert a stringent control over survival and proliferation, impart polarity and organize and remodel the cytoskeleton during adhesion and migration of many types of carcinoma cells (31).
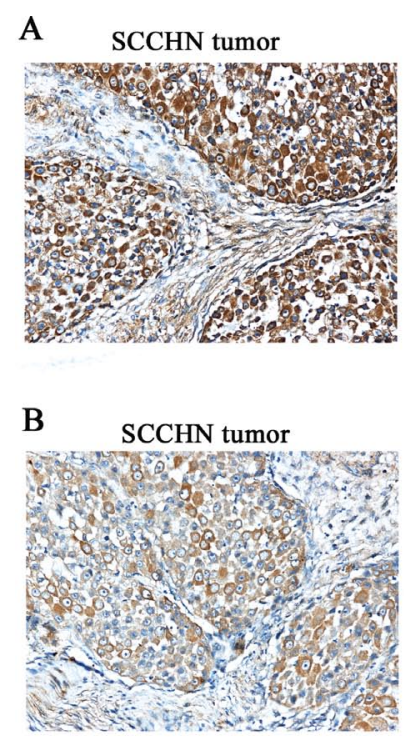
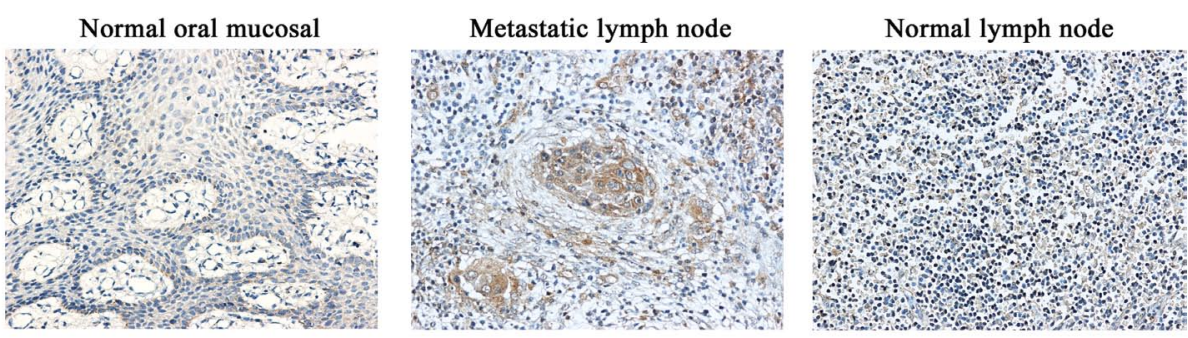

CCR7 immunohistochemical staining

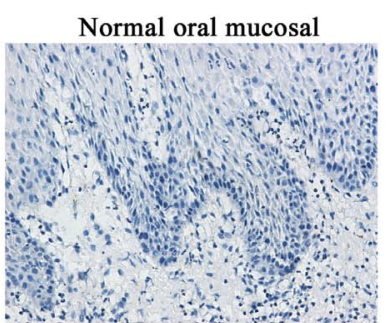

Metastatic lymph node
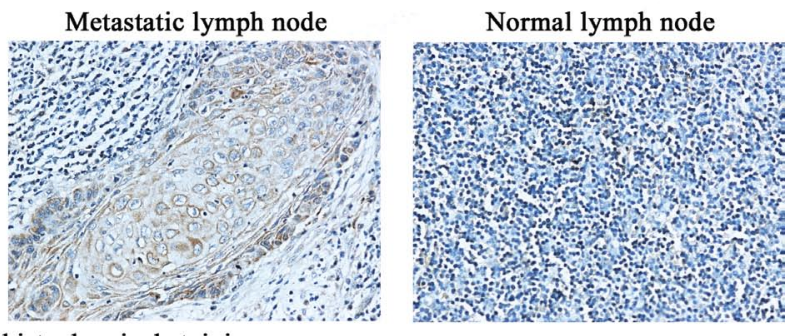

$\operatorname{\alpha v\beta 3}$ integrin immunohistochemical staining

Figure 6. CCR7 and $\alpha v \beta 3$ integrin expression show a significant positive correlation in tumor tissues and metastatic lymph nodes (original magnification, x200). SCCHN tumor tissues, metastatic lymph nodes, normal lymph nodes, and ten normal human oral mucosal tissues showed immunoreactivity for CCR7 (A) and $\alpha v \beta 3$ integrin (B). CCR7 immunoreactivity was mainly observed in the cell membrane and cytoplasm of tumor cells, similar to $\alpha v \beta 3$ integrin staining. Expression of CCR7 and $\alpha v \beta 3$ integrin in normal lymph nodes and normal human oral mucosal tissues was weak or absent. 
Table I. Correlations between the CCR7 and the $\alpha v \beta 3$ integrin expression and clinicopathological features of SCCHN.

\begin{tabular}{|c|c|c|c|c|c|c|c|}
\hline \multirow{2}{*}{$\begin{array}{l}\text { Clinicopathological } \\
\text { characteristics }\end{array}$} & \multirow{2}{*}{$\begin{array}{l}\text { No. of } \\
\text { cases }\end{array}$} & \multicolumn{2}{|c|}{ CCR7 } & \multirow{2}{*}{$\begin{array}{l}\text { Statistical } \\
\text { analysis, } \chi^{2}\end{array}$} & \multicolumn{2}{|c|}{$\alpha v \beta 3$ integrin } & \multirow{2}{*}{$\begin{array}{l}\text { Statistical } \\
\text { analysis, } \chi^{2}\end{array}$} \\
\hline & & $(+)-(+++)$ & $(-)$ & & $(+)-(+++)$ & $(-)$ & \\
\hline \multicolumn{8}{|l|}{ Age } \\
\hline$\geq 60$ & 40 & 25 & 15 & 0.032 & 16 & 24 & 1.821 \\
\hline$<60$ & 38 & 23 & 15 & & 21 & 17 & \\
\hline \multicolumn{8}{|l|}{ Gender } \\
\hline Male & 50 & 32 & 18 & 0.357 & 30 & 20 & 2.122 \\
\hline Female & 28 & 16 & 12 & & 12 & 16 & \\
\hline \multicolumn{8}{|l|}{ Tumor size } \\
\hline $\mathrm{T} 1, \mathrm{~T} 2$ & 65 & 37 & 28 & 3.510 & 22 & 43 & $4.283^{\mathrm{a}}$ \\
\hline $\mathrm{T} 3, \mathrm{~T} 4$ & 13 & 11 & 2 & & 9 & 4 & \\
\hline \multicolumn{8}{|l|}{ Clinical stage } \\
\hline I, II & 37 & 15 & 22 & $13.113^{\mathrm{a}}$ & 9 & 28 & $18.562^{\mathrm{a}}$ \\
\hline III, IV & 41 & 33 & 8 & & 30 & 11 & \\
\hline \multicolumn{8}{|l|}{ Nodal metastasis } \\
\hline Yes & 37 & 29 & 8 & $8.434^{\mathrm{a}}$ & 19 & 18 & $10.283^{\mathrm{a}}$ \\
\hline No & 41 & 19 & 22 & & 7 & 34 & \\
\hline
\end{tabular}

${ }^{\mathrm{a}} \mathrm{P}<0.05$ (difference in CCR7 or $\alpha \mathrm{v} \beta 3$ integrin expression relative to clinicopathological characteristics); (-), $<10 \%$ or no staining; (+), $11-50 \%$; $(++), 50-75 \%$ and $(+++),>75 \%$ positive staining.

CCR7 has been shown to interact with chemokines (CCL19, CCL21) and modulate migration, invasion and proliferation of metastatic SCCHN $(10,11,28)$. However, the mechanisms and the signaling pathways underlying CCR7mediated adhesion and migration remain poorly understood. In the present study we show that $\mathrm{CCR} 7$ regulates cell adhesion and migration in metastatic SCCHN via $\alpha v \beta 3$ integrin. CCR7 and integrins are transmembrane proteins. Signal transduction through these proteins leads to the activation of $\mathrm{G}$ proteins and phospholipase $\mathrm{C}$ and the elevation of cytosolic free calcium. The chemokine CCL21 induces the adhesion of non-small lung cancer cells to vascular cell adhesion molecule-1 (VCAM-1) by activating integrin through a $\mathrm{G}$ protein-coupled receptor (22).

$\alpha v \beta 3$ integrin has been suggested to play a crucial role in mediating the adhesion and arrest of other cell types in endothelial vessels of the lymph nodes, in accordance to its induced invasion of HeLa (32), ovarian cancer (33) and other carcinoma cells (13-16). It has been reported that $\alpha v \beta 3$ integrin can be activated by certain members of the chemokine family, including CCR9 (CCL25 ligand) (34) and CXCR4 (CXCL12 ligand) $(2,21,35)$, but little information is available regarding its interaction with CCR7 (CCL19 and CCL21 ligands), especially in SCCHN. Our results show that stimulation with CCL19 resulted in increased adhesion and migration of SCCHN cells. CCR7 induced the activation of $\alpha v \beta 3$ integrin, which interacted with effector molecules such as intercellular adhesion molecule-1 (ICAM-1), VCAM-1 and mucosal address in cellular adhesion molecule-1 (MadCAM-1). Similar to previous reports, we found that inhibition of $\alpha v \beta 3$ integrin led to a concomitant inhibition of CCL19-induced adhesion and migration of SCCHN cells.

Cancer metastasis organ selectivity is regulated not only by tumor cell migration but also by adhesion at the target organs. This integrin-mediated adhesion, which can be induced by $\mathrm{CCR} 7$, has been reported to regulate the migration of lymphocytes to the lymph node (36). In this study, we used the MTT, Transwell migration assay and the Monolayer wound assay to show that CCL19-induced activation of $\alpha v \beta 3$ integrin significantly enhanced the adhesion (Fig. 1) and migration (Fig. 2 and Fig. 3) indexes of SCCHN cells. These effects were blocked by the $\alpha v \beta 3$ integrin inhibitor, IS201. These results support the hypothesis that CCL19 produced in the lymph nodes might induce SCCHN cell migration into these organs through a CCR7-mediated mechanism. High levels of actin polymerization are required for the formation of pseudopodia, which are needed for chemokine-mediated cell migration and invasion into surrounding tissues as well as efficient metastasis formation (37). We observed that reorganization of the actin cytoskeleton in PCI-37B cells was enhanced by treatment with CCL19, an effect which was inhibited by the RGD-peptide (Fig. 4).

Other studies have shown that CXCL12-induced CXCR4mediated signals can regulate the phosphorylation of $\alpha \mathrm{v} \beta 3$ integrin $(2,21,35)$. Our Western blot analysis shows that stimulation with CCL19 also resulted in increased phosphorylation of $\alpha v \beta 3$ integrin, an effect which was blocked by the CCR7 $\mathrm{mAb}$ and the IS201 inhibitor (Fig. 5), in accordance to previous studies $(21,23)$. $\beta 1$ integrin may indeed be the pertinent downstream target of the CCR7 pathway in this system. 
CCR7 and $\alpha v \beta 3$ integrin have been reported to be highly expressed in various tumors $(6,8,14,16,24,27)$, consistent with the findings of the present study. Our immunohistochemical analysis of 78 cases confirmed the presence of CCR7 and $\alpha v \beta 3$ integrin in the cytoplasm and cell membrane of SCCHN tumor tissues and metastatic lymph nodes. Expression of these proteins was significantly correlated with cervical lymph node metastasis and clinical stage, such that it was low or absent in normal lymph nodes and oral mucosal tissues. CCR7 expression was proposed as a novel predictive biomarker of cancer metastasis. Future studies that include immunohistochemical analysis of both CCR7 and $\alpha v \beta 3$ integrin might be used to predict lymph node metastasis (30). We propose that CCR7 stimulation by CCL19 leads to $\alpha v \beta 3$ integrin activation, which in turn promotes SCCHN modulation of adhesion molecules, cell migration and actin polymerization.

Taken together, the present study supports a novel hypothesis that CCR7 regulates not only migration but also the adhesion of metastatic SCCHN cells via $\alpha v \beta 3$ integrin. CCR7 and $\alpha v \beta 3$ integrin might therefore serve as target molecules for SCCHN therapy aimed to prevent metastasis to lymph nodes. Further studies are still needed to elucidate the molecular mechanism by which CCR7 triggers $\alpha v \beta 3$ integrin and to determine whether this is a unique or ubiquitous phenomenon. The $\alpha v \beta 3$ integrin inhibitor, IS201, is an interesting candidate for the development of novel therapies for the treatment of SCCHN, which deserve further attention and study. It is not expected that inhibition of the CCR7- $\alpha v \beta 3$ integrin pathway can cure tumors; however, clinicians might improve patient prognosis by blocking CCR7- $\alpha \mathrm{v} \beta 3$ integrin in conjunction with other factors in adjuvant chemotherapy thus providing us with a novel therapeutic approach that may improve the prognosis of SCCHN patients.

\section{Acknowledgements}

We are grateful to the University of Pittsburgh Cancer Institute, USA, for supplying the PCI-37B cell line. We thank Mr. Zhong Ming and Mr. Zong Zhihong for their excellent technical assistance. These experiments benefited from many fruitful conversations with members of the Department of Central Laboratory, School of Stomatology, China Medical University. This research was supported by grants from the National Natural Science Foundation of China (no. 30672331) and the Foundation of Education Bureau of Liaoning Province, China (no. 2009A755).

\section{References}

1. Chambers AF, Groom AC and MacDonald IC: Dissemination and growth of cancer cells in metastatic sites. Nat Rev Cancer 2: 563-572, 2002.

2. Yoon Y, Liang Z, Zhang X, Choe M, Zhu A, Cho HT, Shin DM, Goodman MM, Chen ZG and Shim H: CXC chemokine receptor-4 antagonist blocks both growth of primary tumor and metastasis of head and neck cancer in xenograft mouse models. Cancer Res 67: 7518-7524, 2007.

3. Younes MN, Yigitbasi OG, Yazici YD, Jasser SA, Bucana CD, EI-Naggar AK, Mills GB and Myers JN: Effects of the integrinlinked kinase inhibitor QLT0267 on squamous cell carcinoma of the head and neck. Arch Otolaryngol Head Neck Surg 133: $15-23,2007$.

4. Yanagawa Y and Onoé K: CCL19 induces rapid dendritic extension of murine dendritic cells. Blood 100: 1948-1956, 2002.
5. Nagira M, Imai T, Yoshida R, Takagi S, Iwasaki M, Baba M, Tabira Y, Akagi J, Nomiyama $\mathrm{H}$ and Yoshie O: A lymphocytespecific CC chemokine, secondary lymphoid tissue chemokine (SLC), is a highly efficient chemoattractant for B cells and activated T cells. Eur J Immunol 28: 1516-1523, 1998.

6. Takanami I: Overexpression of CCR7 mRNA in non small cell lung cancer: correlation with lymph node metastasis. Int $\mathbf{J}$ Cancer 105: 186-189, 2003.

7. Zlotnik A: Chemokines and cancer. Int J Cancer 119: 2026-2029, 2006.

8. Arigami T, Natsugoe S, Uenosono $\mathrm{Y}$, Yanagita S, Arima $\mathrm{H}$, Hirata M, Ishigami S and Aikou T: CCR7 and CXCR4 expression predicts lymph node status including micrometastasis in gastric cancer. Int J Oncol 35: 19-24, 2009.

9. Günther K, Leier J, Henning G, Dimmler A, Weissbach R, Hohenberger W and Förster R: Prediction of lymph node metastasis in colorectal carcinoma by expression of chemokine receptor CCR7. Int J Cancer 116: 726-733, 2005.

10. Liu FY, Zhao ZJ, Li P, Ding X, Zong ZH and Sun CF: Mammalian target of rapamycin (mTOR) is involved in the survival of cells mediated by chemokine receptor 7 through PI3K/Akt in metastatic squamous cell carcinoma of the head and neck. Br J Oral Maxillofac Surg 48: 291-296, 2010.

11. Li P, Zhao ZJ, Liu FY, Sun LY, Ding X, Zhang WZ, Shang DH and Sun CF: The chemokine receptor 7 regulates cell adhesion and migration via $\beta 1$ integrin in metastatic squamous cell carcinoma of the head and neck. Oncol Rep 24: 989-995, 2010.

12. Constantin G, Majeed M, Giagulli C, Piccio L, Kim JY, Butcher EC and Laudanna $\mathrm{C}$ : Chemokines trigger immediate $\beta 2$ integrin affinity and mobility changes: differential regulation and roles in lymphocyte arrest under flow. Immunity 13: 759-769, 2000.

13. Herouy Y, Mellios P, Bandemir E, Stetter C, Dichmann S, Idzko M, Hofmann C, Vanscheidt W, Schopf E and Norgauer J: Autologous platelet-derived wound healing factor promotes angiogenesis via $\alpha v \beta 3$-integrin expression in chronic wounds. Int J Mol Med 6: 515-519, 2000.

14. Liapis H, Flath A and Kitazawa S: Integrin $\alpha v \beta 3$ expression by bone-residing breast cancer metastases. Diagn Mol Pathol 5: 127-135, 1996.

15. Pignatelli M, Cardillo MR, Hanby A and StampGW: Integrins and their accessory adhesion molecules in mammary carcinomas: loss of polarization in poorly differentiated tumors. Hum Pathol 23: 1159-1166, 1992.

16. Cooper $\mathrm{CR}$, Chay $\mathrm{CH}$ and Pienta KJ: The role of $\alpha v \beta 3$ in prostate cancer progression. Neoplasia 4: 191-194, 2002.

17. Carreiras F, Denoux Y, Staedel C, Lehmann M, Sichel F and Gauduchon P: Expression and localization of av integrins and their ligand vitronectin in normal ovarian epithelium and in ovarian carcinoma. Gynecol Oncol 62: 260-267, 1996.

18. Albelda SM, Mette SA, Elder DE, Stawart R, Damjanovich L, Herlyn $M$ and Buck CA: Integrin distribution in malignant melanoma: association of the beta3 subunit with tumor progression. Cancer Res 50: 6757-6764, 1990.

19. Natali PG, Hamby CV, Felding-Habermann B, Liang B, Nicotra MR, Di Filippo F, Giannarelli D, Temponi $M$ and Ferrone S: Clinical significance of $\alpha v \beta 3$ integrin and intercellular adhesion molecule-1 expression in cutaneous malignant melanoma lesions. Cancer Res 57: 1554-1560, 1997.

20. Gingras MC, Roussel E, Bruner JM, Branch CD and Moser RP: Comparison of cell adhesion molecule expression between glioblastoma multiforme and autologous normal brain tissue. J Neuroimmunol 57: 143-153, 1995.

21. Engl T, Relja B, Marian D, Blumenberg C, Müller I, Beecken WD, Jones J, Ringel EM, Bereiter-Hahn J, Jonas D and Blaheta RA: CXCR4 chemokine receptor mediates prostate tumor cell adhesion through alpha5 and beta3 integrins. Neoplasia 8: 290-301, 2006.

22. Koizumi K, Kozawa Y, Ohashi Y, Nakamura ES, Aozuka Y, Sakurai H, Ichiki K, Doki Y, Misaki T and Saiki I: CCL21 promotes the migration and adhesion of highly lymph node metastatic human non-small cell lung cancer Lu-99 in vitro. Oncol Rep 17: 1511-1516, 2007.

23. Banas B, Wörnle M, Merkle M, Gonzalez-Rubio M, Schmid H, Kretzler M, Pietrzyk MC, Fink M, Perez de Lema G and Schlöndorff D: Binding of the chemokine SLC/CCL21 to its receptor CCR7 increases adhesive properties of human mesangial cells. Kidney Int 66: 2256-2263, 2004.

24. Singh S, Singh R, Sharma PK, Singh UP, Rai SN, Chung LW, Cooper CR, Novakovic KR, Grizzle WE and Lillard JW Jr: Serum CXCL13 positively correlates with prostatic disease, prostatespecific antigen and mediates prostate cancer cell invasion, integrin clustering and cell adhesion. Cancer Lett 283: 29-35, 2009. 
25. Jones J, Marian D, Weich E, Engl T, Wedel S, Relja B, Jonas D and Blaheta RA: CXCR4 chemokine receptor engagement modifies integrin dependent adhesion of renal carcinoma cells. Exp Cell Res 313: 4051-4065, 2007.

26. Johnson LA and Jackson DG: Inflammation-induced secretion of CCL21 in lymphatic endothelium is a key regulator of integrin-mediated dendritic cell transmigration. Int Immunol 22: 839-849, 2010

27. Sancho M, Vieira JM, Casalou C, Mesquita M, Pereira T, Cavaco BM, Dias S and Leite V: Expression and function of the chemokine receptor CCR7 in thyroid carcinomas. J Endocrinol 191: 229-238, 2006 .

28. Wang J, Zhang X, Thomas SM, Grandis JR, Wells A, Wells A, Chen ZG and Ferris RL: Chemokine receptor 7 activates phosphoinositide-3 kinase-mediated invasive and prosurvival pathways in head and neck cancer cells independent of EGFR Oncogene 24: 5897-5904, 2005.

29. Freitas VM, Rangel M, Bisson LF, Jaeger RG and MachadoSantelli GM: The geodiamolide $\mathrm{H}$, derived from Brazilian sponge Geodia corticostylifera, regulates actin cytoskeleton, migration and invasion of breast cancer cells cultured in threedimensional environment. J Cell Physiol 216: 583-594, 2008.

30. Liotta LA, Steeg PS and Stetler-Stevenson WG: Cancer metastasis and angiogenesis: an imbalance of positive and negative regulation. Cell 64: 327-336, 1991.
31. Giancotti FG and Ruoslahti E: Integrin signaling. Science 285 : 1028-1032, 1999

32. Liu Y, Zhao F, Gu W, Yang H, Meng Q, Zhang Y, Yang H and Duan Q: The roles of platelet GPIIb/IIIa and alphavbeta3 integrins during HeLa cells adhesion, migration, and invasion to monolayer endothelium under static and dynamic shear flow. J Biomed Biotechnol 2009: 829243, 2009.

33. Moschos SJ, Drogowski LM, Reppert SL and Kirkwood JM: Integrins and cancer. Oncology 21: 13-20, 2007.

34. Scotton CJ, Wilson JL, Milliken D, Stamp G and Balkwill FR Epithelial cancer cell migration: a role for chemokine receptors? Cancer Res 61: 4961-4965, 2001.

35. Aidoudi S, Bujakowska K, Kieffer N and Bikfalvi A: The CXC-chemokine CXCL4 interacts with integrins implicated in angiogenesis. PLoS One 3: e2657, 2008.

36. Nicolson GL: Organ specificity of tumor metastasis: role of preferential adhesion, invasion and growth of malignant cells at specific secondary sites. Cancer Metastasis Rev 7: 143-188, 1988.

37. Van Haastert PJ and Devreotes PN: Chemotaxis: signalling the way forward. Nat Rev Mol Cell Biol 5: 626-634, 2004. 